\title{
CARTA AO VIAJANTE COVID-19
}

\author{
LETTER TO THE TRAVELER COVID-19
}

\begin{abstract}
Alik Wunder ${ }^{1}$
Resumo: Escrevo a você desde o $45^{\circ}$ dia de quarentena. Há 4 meses você decidiu fazer uma viagem entre dois corpos de espécies diferentes, viagem rara, porém possível. Chegou com sua força mutante e rapidamente se proliferou pelo mundo. Vocês, vírus, são um enigma para a biologia, são matérias orgânicas inanimadas, instigantes viajantes entre os seres vivos e os minerais, e podem, de acordo com as circunstâncias, ser uma coisa ou outra. Entidades que ganham vida apenas no encontro com um corpo orgânico dotado de material genético e sistema celular conveniente. Ínfimas partículas orgânicas replicantes, ladrões perspicazes, hospedeiros inteligentes, viajantes entre reinos. Além dos cuidados para não te encontrar fisicamente, tenho feito o exercício diário de te observar, tentando aprender com sua inteligência viral, com sua força replicante, com sua invisibilidade astuta, com sua anárquica metamorfose e com sua inacreditável velocidade. Envolvida pelos sentimentos de medo e de admiração, escrevo o que tenho aprendido com você nestes dias de isolamento.
\end{abstract}

Palavras-chave: Pandemia; aprendizados; Covid-19.

\begin{abstract}
I have written to you since the 45th day of quarantine. 4 months ago you decided to take a trip between two bodies of different species, a rare but possible trip. It arrived with its mutant strength and quickly proliferated around the world. You viruses are an enigma to biology, you are inanimate organic matter, thought-provoking travelers between living beings and minerals, and can, depending on the circumstances, be one or the other. Entities that come to life only in the encounter with an organic body endowed with genetic material and a convenient cellular system. Tiny replicating organic particles, perceptive thieves, intelligent hosts, travelers between kingdoms. In addition to being careful not to meet you physically, I have been doing the daily exercise of watching you, trying to learn from your viral intelligence, your replicating strength, your cunning invisibility, your anarchic metamorphosis and your unbelievable speed. Surrounded by feelings of fear and admiration, I write what I have learned from you in these days of isolation.
\end{abstract}

Keywords: Pandemic; learning; Covid-19.

Prezado viajante Covid-19,

Escrevo a você desde o $45^{\circ}$ dia de quarentena. Há 4 meses você decidiu fazer uma viagem entre dois corpos de espécies diferentes, viagem rara, porém possível. Chegou com sua força mutante e rapidamente se proliferou pelo mundo. Uma viagem triunfante para você, desafiante e arriscada para nós. Sinto toda manhã a sua presença invisível, mesmo quando não saio de casa. Sua invisibilidade é tristemente corporificada em adoecimentos e mortes que já se contam em milhões. Até o dia de hoje, mais de 3 milhões de pessoas já sentiram sua violência em seus corpos, 230.804 morreram, dentre elas 5.901 no Brasil. Em cada unidade destes números, muitas histórias de perdas, recuperações, sofrimentos, aprendizados... Tem sido cada vez mais difícil acordar e dormir com estes números crescentes. A cada dia chegam-me notícias de pessoas cada vez mais próximas que se despedem daqui por sua causa. Ainda não perdi pessoas

\footnotetext{
${ }^{1}$ Universidade Estadual de Campinas, Campinas, SP, Brasil.
} 
que amo - espero que isso não aconteça -, não adoeci e não senti sua violência em mim, ao menos fisicamente; no entanto, sinto você cada dia mais perto. Esta sua viagem te faz cada vez mais forte e veloz, e nós nos sentimos cada vez menores e mais paralisados. Estou em casa, me preparando para esse inexorável encontro e adiando-o o máximo possível, para proteger a mim e a todas as pessoas em minha volta; ganhando tempo para uma batalha inevitável entre minhas células e você, entre o sistema de saúde e sua expansiva ação na cidade.

Vocês, vírus, são um enigma para a biologia, são matérias orgânicas inanimadas, instigantes viajantes entre os seres vivos e os minerais, e podem, de acordo com as circunstâncias, ser uma coisa ou outra. Entidades que ganham vida apenas no encontro com um corpo orgânico dotado de material genético e sistema celular conveniente. Ínfimas partículas orgânicas replicantes, ladrões perspicazes, hospedeiros inteligentes, viajantes entre reinos. Descobri há pouco que vocês nos habitam há milhões de anos e que 7\% do DNA humano é formado por partículas virais que nos invadiram e se tornaram parte de nós no percurso evolutivo. Algumas dessas invasões causaram mutações, anarquias gênicas que possibilitaram a diversificação da vida. Há pesquisas que indicam que o surgimento da placenta pode ter sido efeito de uma ação viral no processo evolutivo dos seres que deram origem aos mamíferos. Somos mais próximos e misturados a vocês do que gostaríamos de imaginar. Vocês são enigmáticos, são seres e não-seres, geram ao mesmo tempo a morte e outras inimagináveis formas de vida. Há aí muito a pensar.

Milhares de cientistas estão, neste momento, buscando conhecer os detalhes desta sua viagem, no desejo incansável por uma vacina ou medicamento eficaz. Milhares de pessoas estão trabalhando nos hospitais, cuidando daqueles que já te encontraram e tiveram uma difícil batalha. E milhões de pessoas, como eu, estão em suas casas, adiando esse temeroso encontro. E o que mais nos resta, além disso? Além dos cuidados para não te encontrar fisicamente, tenho feito o exercício diário de te observar, tentando aprender com sua inteligência viral, com sua força replicante, com sua invisibilidade astuta e com sua inacreditável velocidade. Permito, neste sentido (e apenas neste), ser hospedeira desse seu modo peculiar de existir e, quem sabe, este contágio me faça outra. Você já ensinou muito aos humanos nestes tempos, mostrou-nos que temos em nós uma força mutante inimaginável. O mundo parou, quem imaginou que seria possível? Envolvida pelos sentimentos de medo e de admiração, escrevo o que tenho aprendido com você nesses dias de isolamento.

A nossa casa cresceu, cada canto ganhou mais vida, e o nosso pequeno quintal, como nas palavras do poeta, vai ficando a cada dia maior que o mundo. Nele as interações com o céu, o vento, o sol e as raras chuvas ficaram mais intensas. No pequeno jardim crescem cada vez mais verduras e legumes, os canteiros de flores e folhagens deram espaço a uma horta. Nossa cozinha se encheu de sementes germinando brotos de ervilha, de girassol, de lentilha, de alfafa... De manhã nos divertimos com alquimias verdes em sucos com folhas colhidas no quintal, no almoço as saladas ficaram mais coloridas. Você nos aproximou dos vegetais nestes tempos e, a mim, levou à escolha de alimentar-me daqui para frente preferencialmente deles. Sua viagem, iniciada em uma feira viva de animais silvestres na China, fez-me pensar que sua forte ação virulenta talvez seja uma reação da floresta sobre nós. É urgente um limite, na China, em relação à criação de seres silvestres para alimentação; e, no Brasil, para a expansão da pecuária bovina e do agronegócio da soja, que destroem as matas, os rios e os povos da floresta. Desde sua aparição, decidi fazer do meu corpo uma pequena barreira a esse ciclo violento. Lembrei, nesses dias, da amizade de longos anos que tenho com algumas plantas: a arnica, a babosa, a arruda, o manjericão, o alecrim, a melissa, a rosa branca... Voltei a ter uma conversação sutil e diária com elas. Senti com tristeza a morte da roseira e do alecrim que se foram, sufocados por outras plantas em sua volta. Replantei-os. Passei babosa nos cabelos, fiz chá de melissa, garrafada de arnica, colhi manjericão para a salada, o alecrim seco 
virou fumaça na casa, a arruda foi para detrás das orelhas, a rosa branca me banhou. Sento ao sol quase todas manhãs, recebo seus primeiros raios junto das minhas amigas e me aconchego por alguns minutos em nossa cúmplice irmandade solar.

Eu e meu filho estamos tecendo juntos alguns fios que ficaram soltos desde sua primeira infância. Em alguns destes dias, abrimos frestas para conversas suspensas no tempo. Ficamos revendo memórias e sentimentos, deslocando cuidadosamente um ao outro de nossas perspectivas de mãe e de filho. Aprendi que observo, ensino e cuido, e que ele tem uma observação muito sensível e perspicaz sobre mim, que tem muito a dizer sobre quem sou, me ensina e me cuida mais do que imaginava. Aprecio e cuido nesses dias com carinho dos meus CDs e dos livros de poesia, contos, romances, ensaios filosóficos; organizo-me entre esta constelação de artistas, escritorxs, filósofxs, cantorxs que foram, ao longo dos anos, carinhosamente me cercando. Descobri que minha casa é um precioso relicário de palavras e canções. Nas horas mais difíceis, situo-me por esta luminosa constelação e dou-me conta de que são elas que, há tantos anos, sustentam meu céu.

Sinto nestes tempos com mais intensidade a ação das palavras, ditas e escritas. Com nossos corpos desacelerados, as palavras parecem ter ganhado ainda mais força. Nestes dias em especial, sinto que elas atuam como você, em puro contágio. As palavras criam mundos, é preciso ter constante atenção a esta sua força criadora. O mundo das palavras pode ser leve e sutil e pode ser denso e violento. Dei-me conta de que nenhum afeto deve ser represado. Palavras de agradecimento, de afeto, de desculpas, de admiração, de entusiasmo e de alegria são feitas para serem ditas sempre. Talvez lapidar as palavras seja um dos nossos grandes aprendizados e, mesmo com aqueles que definimos como nossos inimigos, há de se cuidar com as palavras. $\mathrm{O}$ meu maior desafio nestes tempos tem sido devolvê-las com uma força outra, e encontrar na resposta a cada gesto hostil, uma verdadeira suavidade, sem deixar de dar limites. Nos tempos de intensa hostilidade que vivemos no nosso país, este tem sido um dos grandes aprendizados.

Agradeço, viajante, por sua força mutante que atua aqui no meu pequeno mundo da quarentena. Minhas palavras nesta carta não vieram no sentido de te julgar, algumas delas foram duras, talvez porque venham de uma perspectiva demasiadamente humana. Sei que, desde seu milimétrico ponto de vista, esta sua viagem é de pura vida. Desejo que sua ação virulenta entre nós seja rápida e sem grandes danos, mesmo intuindo que infelizmente não será. Desejo que não me leve desse mundo e que poupe também meus amores, minha família, meus amigos, minhas amigas, meus alunos, minhas alunas, colegas de trabalho... E, por fim, desejo que um dia eu não me esqueça do efeito mutante que esta sua insólita viagem deixou por aqui, entre nós e dentro de nós.

Campinas, 30 de abril de 2020

\section{Sobre a autora}

Alik Wunder é professora docente na Faculdade de Educação da Universidade Estadual de Campinas, São Paulo, Brasil. É bióloga, mestre, doutora e pós-doutora em Educação pela Universidade Estadual de Campinas. Atualmente pesquisa artes indígenas e afro-brasileiras, filosofia contemporânea e imagem, em especial, fotografia. É pesquisadora da Linha de Pesquisa Arte e Linguagem em Educação e do Grupo de Estudos Audiovisuais - OLHO. E-mail: awunder@unicamp.br. 